\title{
Exerc Sci
}

\section{일회성 중강도 유산소 운동이 젊은 성인의 대뇌 혈류량과 인지기능에 미치는 영향: 트레드밀 vs. 고정식 에르고미터}

\author{
강예진 ${ }^{1} \mathrm{MS}$, 이루다 ${ }^{2} \mathrm{MS}$, 황문현 ${ }^{3,4} \mathrm{PhD}$, 임명주 ${ }^{3} \mathrm{PhD}$ \\ ${ }^{1}$ 인천대학교 교육대학원 체육교육과, ${ }^{2}$ 인천대학교 대학원 체육학과, ${ }^{3}$ 인천대학교 운동건강학부, ${ }^{4}$ 인천대학교 스포츠과학연구소
}

\section{Acute Effect of Moderate-intensity Aerobic Exercise on Cerebral Blood Flow and Cognitive Function in Young Adults: Treadmill vs. Cycle Ergometer}

\author{
Yejin Kang ${ }^{1}$ MS, Ruda Lee ${ }^{2}$ MS, Moon-Hyon Hwang ${ }^{3,4}$ PhD, Myong-Joo Lim ${ }^{3}$ PhD \\ ${ }^{1}$ Department of Physical Education, Graduate School of Education, Incheon National University, Incheon; ${ }^{2}$ Department of Human Movement Science, Graduate \\ School, Incheon National University, Incheon; ${ }^{3}$ Division of Health \& Kinesiology, Incheon National University, Incheon; ${ }^{4}$ Sport Science Institute, Incheon National \\ University, Incheon, Korea
}

PURPOSE: This study aimed to compare the acute effects of different types (treadmill vs. cycle) of moderate-intensity aerobic exercise on cerebral blood flow and cognitive function in young adults.

METHODS: By a randomized crossover study design, ten participants were initially assigned to either treadmill exercise (TE; $n=5)$ or cycle ergometer exercise $(\mathrm{CE} ; \mathrm{n}=5)$ and then they performed the other with seven-day wash-out period. Both exercises were implemented at the target heart rate corresponding to $70 \%$ of heart rate reserve for 30 minutes. Cognitive function was assessed by the Stroop Color-Word test at pre- and post-exercise. Cerebral blood flow was continuously monitored using near-infrared spectroscopy technique during rest, cognitive function test (CFT), and exercise.

RESULTS: There was a significant group by time interaction in tissue saturation index (TSI) ( $p=.046)$. Post-hoc analysis presented that TSI at post-exercise CFT was higher than during exercise in TE $(p=.02)$. In both exercises, TSI at pre-exercise CFT significantly increased compared to the resting value $(p=.001)$. Cerebral oxyhemoglobin level was significantly increased during exercise and at post-exercise CFT compared to the resting value in both exercises $(p<.001)$. The reaction time for certain cognitive tasks such as color, word with matched color, word with color interference, and color with word interference was improved after both exercises $(p<.05)$.

CONCLUSIONS: One-bout of moderate-intensity aerobic exercise acutely improves cerebral blood flow and cognitive function even in healthy young adults. Exercise types with the same intensity do not seem to make meaningful difference in the positive effects of aerobic exercise.

Key words: Aerobic exercise, Cerebral blood flow, Cognitive function, NIRS, Stroop Color-Word test

\section{서 론}

운동은 뇌신경세포와 혈관의 생성, 뇌신경성장인자와 신경전달물질 의 증가, 시냅스 연결 촉진 등을 통해 뇌를 구조적, 기능적으로 변화시
켜 인지기능을 향상시킨다[1,2]. 운동으로 촉진된 뇌신경성장인자는 뇌신경세포를 활성화시키고, 활성화된 뇌신경세포가 뇌의 에너지 대 사 및 산소 요구량을 증가시켜 결국 뇌로 유입되는 혈류량을 증가시킨 다[3-5]. 따라서 뇌 혈류량의 증가는 대뇌 산소화(cerebral oxygenation)

Corresponding author: Myong-Joo Lim Tel +82-32-835-8697 Fax +82-32-835-0789 E-mail erickadinu.ac.kr

*이 논문은 인천대학교 2018년도 자체연구비(국내연구) 지원에 의하여 연구되었음.

Keywords 유산소성 운동, 뇌혈류량, 인지기능, 근적외선분광법, 스트룹 색채-단어 검사

Received 13 Mar 2020 Revised 31 Mar 2020 Accepted 20 April 2020

(a)This is an Open Access article distributed under the terms of the Creative Commons Attribution Non-Commercial License (https://creativecommons.org/licenses/by-nc/4.0/) which permits unrestricted non-commercial use, distribution, and reproduction in any medium, provided the original work is properly cited. 
의 증가를 의미하며, 이는 활성화된 뇌기능과[3,4] 인지기능의 향상을 반영한다[6].

선행연구에 따르면 중강도 유산소 운동이 인지기능 개선에 효과적 이며[6,7], 일회성 유산소 운동 수행만으로도 인지기능 개선에 긍정적 인 영향을 주는 것으로 나타났다[8]. 또한 비침습적으로 대뇌 전전두 엽 혈류량를 측정하는 근적외선분광법(Near-infrared spectroscopy, NIRS)을 이용한 연구들은, 운동이 대뇌 혈류량 및 산소화된 헤모글로 빈의 농도를 증가시켜 대뇌 전전두엽 활성화 및 인지기능 개선에 관여 하는 것으로 보고하고 있다[4,5,9-11].

인지기능과 뇌 혈류량에 미치는 운동의 효과는 연령, 운동형태, 운 동강도, 운동기간 등에 따라 상이하게 나타난다. 선행연구에서 아동 및 노인의 경우 일회성 유산소 운동 후 인지기능의 개선 효과가 일관 되게 나타난 반면[12-14], 건강한 젊은 성인의 경우는 운동의 인지기능 개선 효과가 명확하지 않은 것으로 나타났다[15,16]. 운동강도와 관련 한 선행연구 결과를 살펴보면 저, 중강도의 운동은 대뇌 산소화 및 인 지기능을 개선시키지만, 피로를 유발하는 수준의 고강도 운동은 대뇌 에서 산소화된 헤모글로빈의 농도를 감소시켜 일시적인 뇌기능 저하 현상을 유발할 수 있는 가능성을 암시하고 있다 $[4,5,17,18]$. 이와 같이 중강도의 유산소 운동이 노인과 아동의 뇌 혈류량과 인지기능 개선에 도움을 주는 것은 어느정도 알려진 사실이지만, 건강한 젊은 성인의 뇌 혈류량과 인지기능에 미치는 효과에 대해서는 과학적 검증이 필요 한 실정이다. 또한 대부분의 선행연구에서 사용한 유산소 운동형태가 고정식 자전거이기 때문에, 중강도 유산소 운동이 젊은 성인의 뇌 혈 류 및 인지기능에 미치는 효과를 보다 세밀하게 검증하기 위하여 하체 를 위주로 사용하는 유산소 운동과 전신을 사용하는 유산소 운동형 태 간에 운동효과의 차이가 있는지 여부도 검증할 필요가 있다. 따라 서 본 연구에서는 건강한 젊은 성인을 대상으로 서로 다른 형태의 중 강도 일회성 유산소 운동을 실시한 후 운동이 뇌 혈류량과 인지기능 에 미치는 효과를 비교, 분석하고 뇌 혈류량의 변화와 인지기능 간의 관련성을 살펴보고자 한다.

\section{연구 방법}

\section{1. 연구 대상}

본 연구에서는 임상 질환 및 근골격계 기능 장애가 없는 건강한 20 대 성인 남녀 10 명(남성 5 명, 여성 5 명)을 모집하였다. 연구 개시 전, 모 든 연구참여자는 연구의 목적과 절차에 대한 충분한 설명을 듣고 자발 적으로 참여동의서를 작성, 제출하였다. 본 연구는 인천대학교 기관생 명윤리위원회의 심의 절차를 거친 후 수행되었다(7007971-201801-009).

연구대상자의 기본적인 신체적 특성은 Table 1과 같다.
Table 1. Participants' characteristics

\begin{tabular}{lc}
\hline Variables & Mean \pm SE \\
\hline Age $(\mathrm{yr})$ & $23 \pm 1$ \\
Height $(\mathrm{cm})$ & $167.6 \pm 1.7$ \\
Weight $(\mathrm{kg})$ & $61.8 \pm 2.2$ \\
BMI $\left(\mathrm{kg} / \mathrm{m}^{2}\right)$ & $21.9 \pm 0.4$ \\
Muscle mass $(\mathrm{kg})$ & $27.4 \pm 1.1$ \\
Fat mass $(\mathrm{kg})$ & $12.9 \pm 0.7$ \\
Body fat $(\%)$ & $20.8 \pm 0.9$ \\
Resting heart rate $(\mathrm{beats} / \mathrm{min})$ & $57 \pm 2$ \\
Brachial SBP $(\mathrm{mmHg})$ & $118 \pm 2$ \\
Brachial DBP $(\mathrm{mmHg})$ & $70 \pm 2$ \\
\hline
\end{tabular}

Values are mean $\pm \mathrm{SE}$.

BMI, body mass index; SBP, systolic blood pressure; DBP, diastolic blood pressure.

\section{2. 연구 절차 및 측정 방법}

본 연구는 교차설계(cross-over design)를 적용하여 일회성 중강도 유산소 운동유형에 따른 뇌 혈류량과 인지기능의 변화를 비교, 분석 하였다. 모든 연구참여자는 측정 전 최소 12 시간의 공복 상태를 유지 하였으며, 과격한 운동, 카페인, 음주, 흡연을 제한한 상태에서 오전에 실험실을 방문하였다. 실험 시작 전, 연구참여자의 신장, 체중 및 신체 구성을 측정하였으며, 누워서 10 분간 충분한 휴식을 취한 후, 안정 시 혈압과 심박수를 평가하였다. 기본 측정을 마친 연구참여자는 좌측 전 전두엽 부위에 NIRS 장비를 착용한 후 앉은 상태에서 안정 시 전전두 엽의 뇌 혈류량 측정 및 인지기능 평가에 참여하였다. 1 차 실험 시 연 구참여자는 트레드밀 운동(TE) 또는 고정식 에르고미터 운동(CE)에 무작위 순서로 배정되어 일회성 중강도 유산소 운동을 실시하였고, 선 행연구에서 일회성 운동이 뇌혈류량 변화에 미치는 영향을 최소화시 키기 위해 최소 휴식시간으로 제시한 운동 종료 5 분 후 연구참여자는 의자에 앉은 상태에서 전전두엽 뇌 혈류량 측정 및 인지기능 평가에 참여하였다[4]. 운동의 급성 효과가 생체 기능에 미치는 영향을 최소 화시키기 위하여 연구참여자는 일주일의 휴식기를 가진 후 2 차 실험 에 참여하였으며 $[19], 2$ 차 실험 시 연구참여자는 1 차 실험에서 수행했 던 운동유형이 아닌 다른 운동유형에 배정되어 동일 강도의 일회성 유산소 운동을 실시하였다. 1 차와 2 차 실험 방문 시, 일회성 운동 전과 운동 후 동일한 순서와 절차에 따라 주요 생리적 변인이 측정되었다.

\section{1) 일회성 운동 프로토콜}

일회성 중강도 유산소 운동은 트레드밀(T150, h/p/cosmos, Germany)과 고정식 자전거(Fluid Ergometer, First degree Fitness, USA)를 사용 하여 실시하였다. 운동강도는 ACSM의 권고지침[20]과 선행연구[7,21] 를 참고하여 개인별 최대능력의 $70 \%$ 수준에 해당하는 목표심박수를 Karvonen 공식[22]을 이용하여 산출하였다. 운동 시작 전 무선 심박수 
측정기(Polar)를 착용하여 운동 중 심박수의 변화 및 운동강도를 실시 간으로 모니터링하였으며, 트레드밀 운동의 경우 경사와 속도를 조절 하여, 고정식 자전거 운동의 경우 페달링 속도와 페달 부하를 조절하 여 연구참여자가 설정된 목표심박수를 유지할 수 있도록 하였다. 운동 시작과 함께 3 분간의 준비운동을 통해 점진적으로 심박수를 올린 후 목표심박수에 도달하면 심박수를 유지하면서 30 분간 본 운동을 실시 하였다. 정리운동은 본 운동 종료 후 약 3 분 동안 수행되었다.

\section{2) 신체계측 및 신체구성}

신장 $(\mathrm{cm})$ 은 신장계(삼화계기, Korea)를 사용하여 계측하였으며, 신 체구성은 생체전기임피던스법(Inbody 720, Biospace, Korea)을 이용하 여 측정하였다. 신체구성 측정을 통해 체중 $(\mathrm{kg})$, 골격근량 $(\mathrm{kg})$, 체지방 량 $(\mathrm{kg})$, 체질량지수 $\left(\mathrm{kg} / \mathrm{m}^{2}\right)$, 체지방률(\%)을 평가하였다.

\section{3) 뇌혈류 측정}

연구참여자의 대뇌 혈류량과 산소포화도를 객관적으로 측정하기 위해 근적외선 분광법(Near-infrared spectroscopy, NIRS)을 이용한 장 비인 PortaLite (Artinis Medical Systems BV, Zetten, Netherlands)를 사 용하였다. NIRS 센서를 좌측 눈썹 위 $1-2 \mathrm{~cm}$ 정도 지점인 대뇌 전전두 엽 부위에 위치시키고 접착 테이프를 붙인 후, 검은색 헤어 두건을 쓰 워 운동 중 움직임이나 땀으로부터 분리되지 않도록 고정시켰으며 주 변의 빛 침투를 제한하였다. 측정은 크게 4 단계의 시점으로 구분하여 안정 시, 운동 전 인지기능 검사 시, 운동 수행 중, 운동 후 인지기능 검 사 시 동안에 실시되었으며, 측정 중 750-850 nm의 다양한 깊이의 파 장으로부터 획득된 정보에 의해 산소화헤모글로빈 농도(Oxyhemoglobin, $\mathrm{O}_{2} \mathrm{Hb}$ )와 조직의 산소포화 지수(Tissue Saturation Index, TSI)가 평 가되었다. 측정된 값은 블루투스를 통해 컴퓨터로 전달되고 자동화된 소프트웨어(Oxysoft, Artinis Medical Systems, Zetten, Nethelands)를 통 해 $10 \mathrm{~Hz}$ 의 출력 주파수로 1 초당 변화되는 평균값으로 기록되었다. 시 점 별 마지막 60 초 동안의 평균값을 데이터 분석에 사용하였으며, 안 정 시의 값을 기준으로 하여 운동 전 인지기능 검사 시(CFT_pre), 운동 수행 중 $(\mathrm{Ex})$, 운동 후 인지기능 검사 시(CFT_post)의 산소화헤모글로 빈 농도 및 조직의 산소포화 지수의 변화량의 값을 산출하였다.

\section{4) 인지기능 평가}

인지기능 평가는 기존의 신경인지기능 평가도구의 문제점을 보완하 여 개발된 전산화된 한국형 종합 신경인지기능 평가(Comprehensive Neurocognitive Function Test, CNFT, Medise, Korea) 소프트웨어를 사 용하여 전두엽 및 고위인지기능을 평가할 수 있는 스트룹 색채-단어 검사를 실시하였다. 검사는 단어읽기(Word), 색채읽기(Color), 색채가 일치하는 단어읽기(Word-Color Match, Word-M), 색채의 간섭이 부여
된 상태에서 단어읽기(Word-Color Interference, Word-I), 단어의 간섭 이 부여된 상태에서 색채읽기(Color-Word Interference, Color-I)의 순서 로 총 5 가지의 형태로 구성되어 있으며, 각 검사마다 4 열 5 행으로 이루 어진 20 개의 단어가 화면에 제시된다. 전통적인 스트룹 색채-단어 검 사방법과 유사하게[23], 첫 번째 단어읽기 검사는 화면에 검정색으로 제시된 글자들의 단어를 읽고, 두 번째 색채읽기 검사는 화면에 제시 된 색깔막대의 색상을 읽는다. 세 번째 색채가 일치하는 단어읽기 검 사는 단어와 그 해당 단어의 색깔이 일치하는 글자의 단어를 읽는 반 면, 네 번째 색채의 간섭이 부여된 상태에서 단어읽기 검사는 단어와 그 해당 단어의 색깔이 불일치하게 제시되지만 색깔에 상관없이 단어 를 읽어야 한다. 마지막으로 단어의 간섭이 부여된 상태에서 색채읽기 검사는 단어와 그 해당 단어의 색깔이 불일치하게 제시되지만 단어에 상관없이 그 단어에 입혀진 색깔을 읽어야 한다. 측정은 각각의 검사 에 대하여 연구참여자가 가능한 빠르고 정확하게 읽도록 하였으며 기 록된 정답반응시간(reaction time)을 인지기능 평가에 사용하였다. 학 습효과에 따른 오차를 최소화하기 위해 연구참여자가 스트룹 색채-단 어 검사에 익숙해지도록 본 측정 전 2 회의 연습 기회를 제공하였다.

\section{3. 자료처리 방법}

본 연구에서 통계적 자료 분석을 위해 Window용 SPSS version 25 를 사용하였으며, 모든 데이터는 평균(mean)과 표준오차(SE)로 표시하였 다. 유산소 운동형태와 시점에 따른 종속변인의 차이를 분석하기 위하 여 반복측정분산분석(ANOVA with repeated measure)을 실시하였고, 사후검증은 Bonferroni's method를 이용하였다. 부가적으로 그룹별 운 동중재에 따른 종속변인의 변화를 알아보기 위해 Bonferroni correction을 적용한 paired t-test를 실시하였으며, 특정 시점별 그룹 간 차이 를 알아보기 위해 Independent t-test를 실시하였다. 또한 뇌 혈류와 인 지기능 간의 관련성을 분석하기 위해 Pearson's correlation을 실시하였 으며 정규성이 나타나지 않은 변인의 경우 자연로그(LN) 치환 후 상관 관계를 분석하였다. 본 연구에서 Bonferroni correction을 적용한 분석 을 제외한 나머지 통계적 유의수준은 $p<0.05$ 로 설정하였다.

\section{연구결과}

\section{1. 뇌 혈류 변인}

일회성 중강도 유산소 운동유형에 따른 대뇌 혈류량의 변화는 Fig. 1 에 제시한 바와 같다. 반복측정분산분석 결과 TSI에서 그룹과 시점간 유의한 상호작용이 나타났으며 $(p=.046)$, 사후검증 결과 TE에서만 운 동 중과 운동 후 인지기능 검사 시 간 TSI에 유의한 차이가 나타났다 $(p=.016)$. 또한 TE와 $\mathrm{CE}$ 모두 안정 시에 비해 인지기능 검사 시 $\mathrm{TSI} \%$ 가 유의하게 증가했다 $(p<.05)$ (Fig. $1 \mathrm{~A}) . \mathrm{O}_{2} \mathrm{Hb}$ 는 그룹과 시점 간 상호작용 

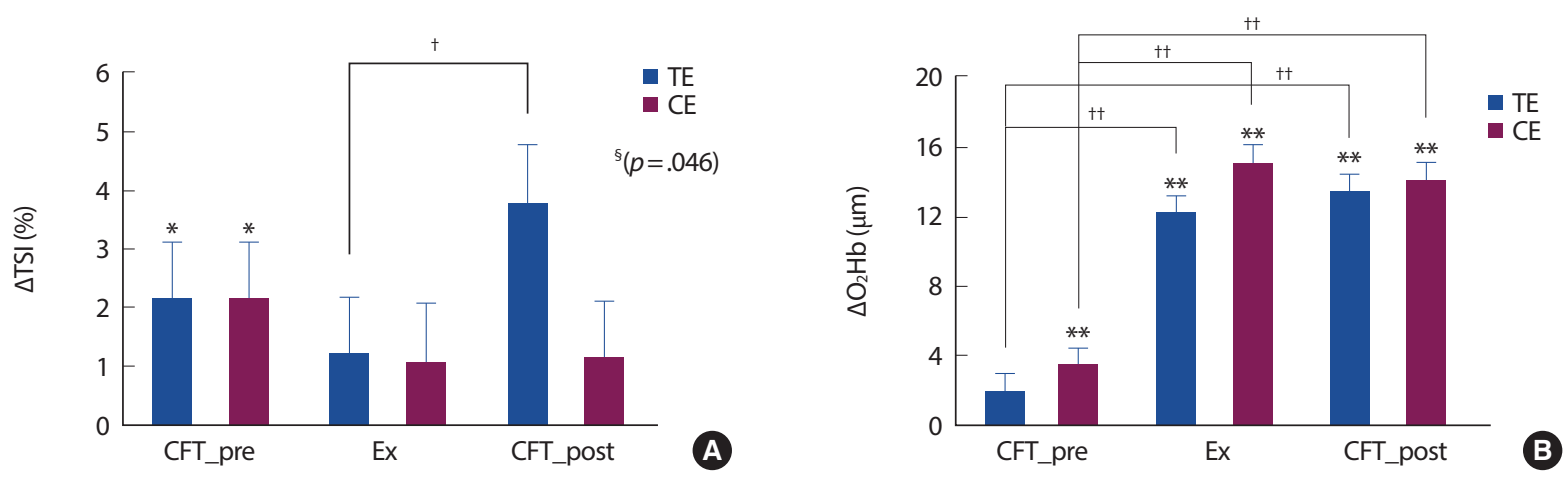

Fig. 1. Changes in cerebral blood flow index according to exercise types during cognitive function test at pre- and post-exercise and one-bout of aerobic exercise. Values are mean $\pm \mathrm{SE}$. TSI\%, tissue saturation index; $\mathrm{O}_{2} \mathrm{Hb}$, oxyhemoglobin; $\mathrm{TE}$, treadmill exercise; $\mathrm{CE}$, cycle ergometer exercise; $\mathrm{CFT}$-pre, cognitive function test before exercise; Ex, during exercise; CFT_post, cognitive function test after exercise. All values were expressed as changes from the baseline value. ${ }^{\S}$ Significant time by group interaction $(p<.05)$; ${ }^{*}$ Significant difference from the baseline value $\left({ }^{*} p<.05,{ }^{* *} p<.001\right) ;{ }^{\dagger}$ Significant difference between certain time points in the same group $\left({ }^{\dagger} p<.05,{ }^{+\dagger} p<.001\right)$.

Table 2. Changes in cognitive function after two different types of one-bout of aerobic exercise

\begin{tabular}{|c|c|c|c|c|c|}
\hline \multirow{3}{*}{$\begin{array}{l}\text { Variables } \\
\text { Word (sec) }\end{array}$} & \multirow{3}{*}{$\begin{array}{c}\text { Group } \\
\text { TE }\end{array}$} & \multicolumn{2}{|c|}{ Reaction time } & \multirow{2}{*}{\multicolumn{2}{|c|}{ F-value }} \\
\hline & & \multirow{2}{*}{$\begin{array}{c}\text { pre } \\
10.48 \pm 0.75\end{array}$} & \multirow{2}{*}{$\begin{array}{c}\text { post } \\
9.65 \pm 0.39\end{array}$} & & \\
\hline & & & & Time & $7.050^{+}$ \\
\hline & CE & $10.37 \pm 0.47$ & $9.51 \pm 0.40$ & Time *Group & 0.002 \\
\hline \multirow[t]{2}{*}{ Color (sec) } & TE & $12.34 \pm 0.73$ & $10.77 \pm 0.60^{*}$ & Time & $13.014^{+\dagger}$ \\
\hline & & & & Group & 0.474 \\
\hline \multirow[t]{3}{*}{ Word-M (sec) } & TE & $9.63 \pm 0.48$ & $8.58 \pm 0.42^{* *}$ & Time & $37.658^{+\dagger}$ \\
\hline & & & & Group & 0.041 \\
\hline & CE & $9.98 \pm 0.36$ & $8.45 \pm 0.38^{* *}$ & Time*Group & 1.280 \\
\hline \multirow[t]{2}{*}{ Word-I (sec) } & TE & $10.79 \pm 0.53$ & $8.89 \pm 0.36^{*}$ & Time & $17.098^{+\dagger}$ \\
\hline & & & & Group & 1.075 \\
\hline
\end{tabular}

Values are mean $\pm \mathrm{SE}$.

$\mathrm{TE}$, treadmill exercise; $\mathrm{CE}$, cycle ergometer exercise; Word, the task to read words; Color, the task to read colors; Word-M, the task to read words matched with their colors; Word-I, the task to read words regardless of words' color (words with color interference); Color-I, the task to read words' color regardless of words (colors with word interference).

${ }^{\dagger}$ Significant time effect $\left({ }^{\dagger} p<.05,{ }^{\dagger \dagger} p<.005\right)$; ${ }^{*}$ Significant difference between pre and post $\left({ }^{*} p<.05,{ }^{* *} p<.005\right)$.

이 나타나지 않았지만 시기에 따른 주효과가 나타났다 $(p<.001) . \mathrm{TE}$ 와 $\mathrm{CE}$ 모두 안정 시에 비해 운동 중과 운동 후 인지기능 검사 시에 $\mathrm{O}_{2} \mathrm{Hb}$ 가 유의하게 증가했다 $(p<.001)$ (Fig. 1B).

\section{2. 스트룹 색채-단어 검사}

일회성 중강도 유산소 운동유형에 따른 스트룹 색채-단어 검사 결 과는 Table 2에 제시된 바와 같다. 반복측정분산분석 결과 그룹과 시 점 간 유의한 상호작용은 나타나지 않았지만, 모든 변인에서 시기에 따른 주효과가 나타났다 $(p<.05)$. 대응표본 t-test를 통해 그룹별 종속요
인의 변화를 분석한 결과, TE와 $\mathrm{CE}$ 모두 운동 전에 비해 운동 후 Color, Word-M, Word-I, Color-I에서 정답 반응시간이 유의하게 감소하였 다 $(p<.05)$.

\section{3. 뇌 혈류와 인지기능 간의 관련성}

일회성 중강도 유산소 운동에 따른 뇌 혈류량의 변화와 인지기능 변화간 관련성은 Fig. 2 에 제시된 바와 같다. 운동 전 인지기능 검사 시 와 운동 후 인지기능 검사 시 간 뇌 혈류량 변인의 변화와 스트룹 색 채-단어 검사 결과의 변화에 대한 관련성을 분석한 결과, 통계적으로 


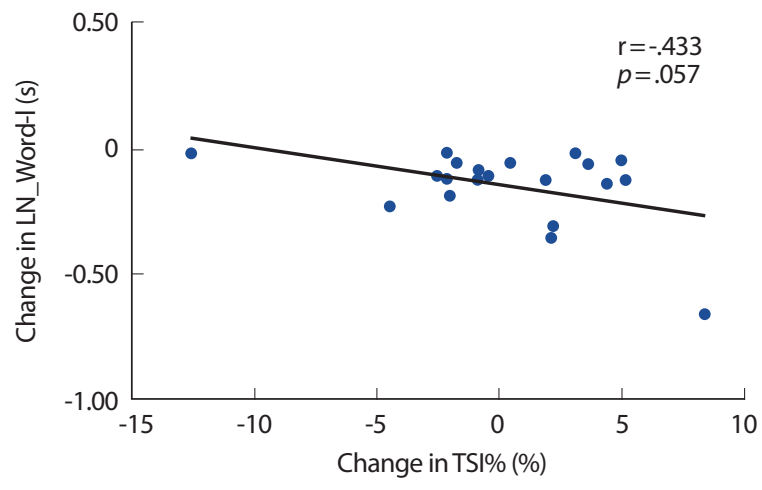

Fig. 2. Correlations between cerebral blood flow and cognitive function. TSI\%, tissue saturation index; LN_Word-I, natural logarithm of the task value to read words regardless of words' color (words with color interference). All values were calculated as the difference between pre and post-exercise intervention.

유의한 상관관계가 나타나지 않았지만, 운동 전, 후 자연로그로 치환 한 Word-I 값의 변화와 TSI\% 변화 간에 중등도의 상관성이 나타났다 $(r=.43, p=.057)$.

\section{논 의}

본 연구는 일회성 중강도 유산소 운동이 젊은 성인의 뇌 혈류와 인 지기능에 미치는 영향을 알아보기 위하여 대뇌의 조직 산소포화 지수 (TSI\%)와 산소화헤모글로빈 농도 $\left(\mathrm{O}_{2} \mathrm{Hb}\right)$ 측정 및 스트룹 색채-단어 검 사를 실시하였으며, 뇌 혈류와 인지기능 간의 관련성을 분석하였다.

최근 대뇌 혈류량을 평가한 상당수의 연구에서 비침습적, 연속적, 직접적으로 혈중 산소 농도의 변화를 측정, 분석할 수 있는 근적외선 분광법(Near-infrared spectroscopy, NIRS)을 채택하고 있다[9-11,18,24]. 본 연구에서도 NIRS를 활용하여 일회성 중강도 유산소 운동유형에 따른 뇌 혈류량의 변화를 분석한 결과, TSI\%에서 그룹과 시점간 유의 한 상호작용이 나타났다. 사후검증 결과, 트레드밀 운동에서는 운동 중에 비해 운동 후 인지기능 검사 시 TSI\%가 유의하게 증가한 반면, 고 정식 자전거 운동에서는 유의한 차이가 나타나지 않았다. 또한 트레드 밀과 고정식 자전거 운동 모두 안정 시 보다 인지기능 검사 시 TSI\%가 유의하게 증가했다. 대뇌 피질 중 전전두엽은 고차원적인 인지기능을 조절하는 역할을 담당하고 있기 때문에 운동 시나 인지과제 수행 시 활성화되는 부위로 알려져 있다[5]. 전전두엽에서의 TSI\%는 산소 가용 성(oxygen availability)과 산소 활용(oxygen utilization) 간의 균형을 반 영하는 대뇌 산소화(cerebral oxygenation)를 나타내는 지표로서 활용 된다[25-27]. 따라서 증가된 대뇌 전전두엽 산소화는 활성화된 대뇌 인 지기능을 반영한다[3,4]. Yanagisawa et al. [10]은 인지기능과 관련된 과 제 수행이 전전두엽 피질을 활성화시키고, 더 나아가 일회성 유산소
운동은 대뇌의 산소화를 증가시켜 인지기능 수행과 관련된 좌측 전전 두엽 피질의 활성도를 강화시킨다고 보고하였다. 운동형태와 더불어 유산소 운동 강도 또한 대뇌의 산소화에 영향을 미치는 중요한 요인 으로 알려져 있는데, Ando et al. [27]의 연구는 중강도의 일회성 유산 소 운동만으로도 대뇌 산소화를 유의하게 개선시킬 수 있음을 과학적 으로 입증했다. 앞서 언급한 선행연구 결과와 유사하게 본 연구에서도 안정 시에 비해 인지기능 검사 시 대뇌 전전두엽 산소화가 유의하게 증 가되며, 중강도의 일회성 트레드밀 운동 후에 대뇌 전전두엽 산소화가 유의하게 증가하는 것을 확인했다. 이는 연령과 관계없이 젊은 성인이 라도 인지기능 수행 시 전전두엽이 활성화되어 대뇌에서의 산소 이용 률과 산소화가 증가된다는 점과, 중강도 유산소 운동형태 중 전신을 사용하는 트레드밀 걷기 또는 달리기 운동이 국소적으로 하체 근육을 주로 사용하는 고정식 자전거 운동에 비해 고차원적인 인지기능을 담 당하는 대뇌 전전두엽 산소화에 더욱 효과적인 유산소 운동형태라는 것을 보여준다.

본 연구에서 일회성 중강도 유산소 운동유형에 따른 혈중 산소화헤 모글로빈 농도 $\left(\mathrm{O}_{2} \mathrm{Hb}\right)$ 의 변화를 분석한 결과, 트레드밀 운동과 고정식 자전거 운동에서 모두 안정 시에 비해 운동 중과 운동 후 인지기능 검 사 시에 $\mathrm{O}_{2} \mathrm{Hb}$ 농도가 유의하게 증가했으며, 이는 일회성 중강도 유산 소 운동 동안에 대뇌 전전두엽의 산소화헤모글로빈 농도가 증가된다 는 선행연구의 결과와 일치한다는 것을 보여준다[4,18,21]. 산소화헤모 글로빈 농도는 NIRS로 측정하는 뇌조직 부위의 활성화 정도를 나타내 는 지표이기 때문에, 본 연구에서 산소화헤모글로빈의 농도가 증가된 것은 대뇌 전전두엽 부위가 활성화된 것을 의미한다[9]. 뇌의 주요 에 너지원은 유산소성 대사에 의해 뇌신경세포에 ATP를 공급하기 때문 에[28], 운동 중 활성화된 뇌는 뇌신경세포 대사 요구량을 증가시켜 활 동 중인 골격근과 함께 대뇌에도 산소 공급이 증가되게끔 유도한다 [29]. 따라서, 본 연구결과는 운동으로 인해 활성화된 뇌신경세포가 뇌 에서 필요로 하는 에너지 대사 및 산소 요구량을 증가시켜 결과적으 로 대뇌 전전두엽 혈류량과 조직 내 혈중 산소화헤모글로빈 농도를 증 가시킨 것을 반영한다[3-5]. 또한 본 연구결과는 유산소 운동유형에 관 계없이 일회성 중강도 운동만으로도 운동 중과 운동 후 대뇌 전전두엽 의 산소화헤모글로빈 농도가 증가될 수 있다는 것을 보여주고 있다.

본 연구에서 인지기능을 평가하기 위해 사용한 스트룹 색채-단어 검사는 하나의 자극이 처리되는 동안 또다른 자극의 간섭효과가 부여 될 때, 전두엽의 인지 간섭을 억제하는 능력을 평가할 수 있다[30]. 본 연구에서 일회성 중강도 유산소 운동에 따른 인지기능의 변화를 살펴 본 결과, 유산소 운동유형에 관계없이 트레드밀 운동과 고정식 자전거 운동에서 모두 운동 후 인지기능 검사 시 검사 항목 중 Color, Word-M, Word-I, Color-I에서 정답 반응시간이 유의하게 향상된 것으로 나타났 다. Kamijo et al. [31]은 젊은 성인과 노인 모두 일회성 중강도 유산소 
운동 후에 인지기능 검사의 반응시간이 유의하게 개선되었다고 보고 하였으며, Yanagisawa et al. [10]의 연구에서도 일회성 중강도 유산소 운동이 전전두엽을 활성화시켜 스트룹 색채-단어 검사 시 반응시간을 유의하게 단축시켰다고 보고하였다. 선행연구와 동일하게 본 연구에서 도 유산소 운동 유형에 관계없이 일회성 중강도 운동 수행 후, 인지기 능 검사 도구 중 하나인 스트룹 색채-단어 검사의 반응시간이 유의하 게 감소하였다.

운동을 통한 인지기능 개선에 관여하는 생리적 기전으로 뇌 신경세 포의 생존, 유지, 발달에 관여하고 뇌 신경세포간 시냅스 가소성을 증 진시키는 핵심 단백질인 뇌(-유도) 신경성장인자(brain-derived neurotrophic factor, BDNF), 인슐린 유사성장인자(insulin-like growth factor 1, IGF-1) 및 혈관 내피세포 성장인자(vascular endothelial growth factor, VEGF)를 들 수 있다[32]. 최근 국내에서 발표된 상당수의 관련 선행연 구에서도 운동을 통한 BDNF를 포함한 IGF-1 또는 VEGF의 증가를 보고하였으며[11,32-35], 특히 BDNF는 운동에 대한 반응으로 해마 영 역에서 높은 수준으로 분비되어 인지기능 개선에 기여하는 것으로 알 려져 있다[1,2]. Cotman et al. [1]에 따르면, 운동 수행은 BDNF의 생성 을 증가시키고, 신경세포 내 신호전달체계를 활성화시킴으로써 뇌 기 능을 개선시킨다. 특히, 운동은 신경전달물질, 호르몬 및 IGF-1 분비의 변화를 유발하여 대뇌 해마에서의 BDNF 생성 및 발현을 증가시키고, IGF-1은 BDNF 및 VEGF와 함께 신경세포 및 혈관조직 생성에 관여함 으로써 시냅스 가소성을 향상시킨다. $\mathrm{VEGF}$ 는 뇌신경세포에 영양을 공급하는 혈관 생성 및 확장을 촉진시켜 대뇌 혈류량 증가와 인지기능 개선에 중요한 역할을 담당한다[1,36,37]. 그 외 운동을 통한 인지기능 개선을 설명하는 생리적 기전으로 각성 수준의 증가를 들 수 있다. 운 동은 카테콜라민, 세로토닌, 도파민과 같은 뇌신경전달물질을 증가시 켜[38] 생체의 각성 수준은 높이고, 높아진 각성 수준이 인지 기능을 향상시키는 것으로 보고되고 있다[13,39]. 따라서 본 연구에서 나타난 일회성 중강도 유산소 운동을 통한 인지기능의 개선은 뇌 내부에서 나타나는 국소적 변화와 뇌를 포함한 전신에서 나타나는 다양한 생리 적 변화가 복합적으로 작용하여 인지기능을 개선시킨 것으로 사료된 다. 안타깝게도 본 연구에서는 국소적, 전신적으로 작용하는 바이오마 커를 측정, 분석하지 않았기 때문에 단순히 기능적 변화를 평가하여 관련 생리적 기전을 추론할 수 밖에 없는 제한점을 가지고 있다.

일회성 중강도 유산소 운동에 대한 반응으로 나타나는 뇌 혈류량 의 변화와 인지기능 변화 간 상관관계를 분석한 결과, 통계적인 유의성 까지 도달하지는 못했지만 운동 전후 TSI\%의 차이가 증가할수록 스 트룹 색채-단어 검사 항목 중 Word-I 조건에서 반응시간이 두드러지 게 감소하는 상당한 수준의 상관관계가 나타났다. 이는 대뇌 조직의 산소화가 감소할수록 인지 작업의 반응시간이 느려지고 정확성 또한 감소하는 부적 상관관계가 나타난다고 보고한 Williams et al. [40]의
연구결과와 일회성 유산소 운동 후 대뇌 산소화가 증가할수록 인지 작업의 반응시간이 감소하는 부적 상관관계를 보고한 Mekari et al. [18]의 연구결과를 재확인해주고 있다. 안타깝게도 선행연구와 비교하 여 상대적으로 적은 연구참여자 수는 중강도 일회성 유산소 운동에 대한 반응으로 나타난 대뇌 전전두엽 혈류량의 변화와 인지기능의 변 화 간 상관관계가 통계적 유의성에 도달하지 못한 가장 중요한 원인을 제공하는 것으로 사료된다. 하지만 본 연구에서 보고한 Pearson's correlation coefficient $(\mathrm{r}=-.433)$ 는 변인 간 상당한 관련성을 내포하고 있기 때문에 일회성 중강도 유산소 운동에 대한 반응으로 나타난 젊은 성 인의 대뇌 혈류량 변화와 인지기능 변화 간에 상관관계가 있다고 간주 하는 것이 바람직하다.

\section{결론 및 제언}

일회성 중강도 유산소 운동은 운동 후 일시적으로 젊은 성인의 대뇌 전전두엽 산소화헤모글로빈 농도를 증가시키고 인지기능을 개선시킨 다. 특히 국소적 유산소 운동인 고정식 자전거 운동에 비해 전신성 유 산소 운동인 트레드밀 운동이 운동 후 대뇌 조직의 산소화 증가에 더 효과적이며, 중강도 유산소 운동에 대한 반응으로 나타난 대뇌 전전두 엽 혈류량 증가가 운동 후 인지기능 개선에 부분적으로 관여하는 것으 로 사료된다. 하지만 본 연구는 연구참여자 수가 상대적으로 적고 관련 생리적 기전을 직접 제시하지 못한다는 점, 그리고 운동에 대한 반응을 운동 직후로 한정한다는 제한점을 가지고 있다. 따라서 후속 연구에서 는 다양한 운동강도, 운동종류, 운동기간을 적용하여 운동에 반응 또 는 적응하여 나타나는 대뇌 혈류량과 인지기능의 변화를 분석하고 이 와 관련된 생리적 기전을 규명할 필요가 있다. 또한 다양한 연령층과 손상된 인지기능을 가진 대상을 포함하여 보다 포괄적으로 임상적 효 용성을 입증할 수 있는 후속연구 역시 필요하다고 사료된다.

\section{CONFLICT OF INTEREST}

이 논문 작성에 있어서 어떠한 조직으로부터 재정을 포함한 일체의 지원을 받지 않았으며, 논문에 영향을 미칠 수 있는 어떠한 관계도 없 음을 밝힌다.

\section{AUTHOR CONTRIBUTION}

Conceptualization: Y Kang, MH Hwang; Data curation: Y Kang, R Lee; Formal analysis: Y Kang, MH Hwang; Funding acquisition: MJ Lim; Methodology: Y Kang, R Lee, MH Hwang; Project administration: Y Kang, MH Hwang; Visualization: Y Kang; Writing - original draft: Y 
Kang, MJ Lim; Writing - review \& editing: Y Kang, R Lee, MH Hwang, MJ Lim.

\section{ORCID}

$\begin{array}{ll}\text { Yejin Kang } & \text { https://orcid.org/0000-0002-3436-1846 } \\ \text { Ruda Lee } & \text { https://orcid.org/0000-0003-4886-5903 } \\ \text { Moon-Hyon Hwang } & \text { https://orcid.org/0000-0001-6095-4349 } \\ \text { Myong-Joo Lim } & \text { https://orcid.org/0000-0002-8670-0176 }\end{array}$

\section{REFERENCES}

1. Cotman CW, Berchtold NC, Christie L-A. Exercise builds brain health: key roles of growth factor cascades and inflammation. Trends Neurosci. 2007;30(9):464-72.

2. Voss MW, Vivar C, Kramer AF, van Praag H. Bridging animal and human models of exercise-induced brain plasticity. Trends Cogn Sci. 2013;17(10):525-44.

3. Colier W, Quaresima V, Oeseburg B, Ferrari M. Human motor-cortex oxygenation changes induced by cyclic coupled movements of hand and foot. Exp Brain Res. 1999;129(3):457-61.

4. Ide K, Horn A, Secher NH. Cerebral metabolic response to submaximal exercise. J Appl Physiol. 1999;87(5):1604-8.

5. Rooks CR, Thom NJ, McCully KK, Dishman RK. Effects of incremental exercise on cerebral oxygenation measured by near-infrared spectroscopy: a systematic review. Prog Neurobiol. 2010;92(2):134-50.

6. McMorris T, Hale BJ. Differential effects of differing intensities of acute exercise on speed and accuracy of cognition: a meta-analytical investigation. Brain Cogn. 2012;80(3):338-51.

7. Chang YK, Labban JD, Gapin JI, Etnier JL. The effects of acute exercise on cognitive performance: a meta-analysis. Brain Res. 2012;1453: 87-101.

8. Hillman CH, Pontifex MB, Raine LB, Castelli DM, Hall EE, et al. The effect of acute treadmill walking on cognitive control and academic achievement in preadolescent children. Neurosci. 2009;159(3):104454.

9. Suzuki M, Miyai I, Ono T, Oda I, Konishi I, et al. Prefrontal and premotor cortices are involved in adapting walking and running speed on the treadmill: an optical imaging study. Neuroimage. 2004;23(3): 1020-6.

10. Yanagisawa H, Dan I, Tsuzuki D, Kato M, Okamoto M, et al. Acute moderate exercise elicits increased dorsolateral prefrontal activation and improves cognitive performance with Stroop test. Neuroimage. 2010;50(4):1702-10.

11. Hwang JS. Effect of Exercise Type on Prefrontal Cortex Blood Flow, Cognitive Function and Neurotrophic Factors. [dissertation]. Seoul: Ehwa Womans University 2017.

12. Hillman CH, Kamijo K, Scudder M. A review of chronic and acute physical activity participation on neuroelectric measures of brain health and cognition during childhood. Prev Med. 2011;52:S21-S8.

13. Tomporowski PD. Cognitive and behavioral responses to acute exercise in youths: a review. Pediatr Exerc Sci. 2003;15(4):348-59.

14. Barella LA, Etnier JL, Chang YK. The immediate and delayed effects of an acute bout of exercise on cognitive performance of healthy older adults. J Aging Phys Act. 2010;18(1):87-98.

15. Li L, Men WW, Chang YK, Fan MX, Ji L, Wei GX. Acute aerobic exercise increases cortical activity during working memory: a functional MRI study in female college students. PLoS One. 2014;9(6).

16. Ludyga S, Gerber M, Brand S, Holsboer-Trachsler E, Pühse U. Acute effects of moderate aerobic exercise on specific aspects of executive function in different age and fitness groups: a meta-analysis. Psychophysiology. 2016;53(11):1611-26.

17. Subudhi AW, Dimmen AC, Roach RC. Effects of acute hypoxia on cerebral and muscle oxygenation during incremental exercise. J Appl Physiol. 2007;103(1):177-83.

18. Mekari S, Fraser S, Bosquet L, Bonnéry C, Labelle V, et al. The relationship between exercise intensity, cerebral oxygenation and cognitive performance in young adults. Eur J Appl Physiol. 2015;115(10):218997.

19. Kriel Y, Askew CD, Solomon C. Sprint interval exercise versus continuous moderate intensity exercise: acute effects on tissue oxygenation, blood pressure and enjoyment in 18-30 year old inactive men. PeerJ 2019;7:e7077.

20. Thompson WR, Gordon NF, Pescatello LS. ACSM's guidelines for exercise testing and prescription: Lippincott Williams \& Wilkins; 2010.

21. Lucas SJ, Ainslie PN, Murrell CJ, Thomas KN, Franz EA, et al. Effect of age on exercise-induced alterations in cognitive executive function: relationship to cerebral perfusion. Exp Gerontol. 2012;47(8):541-51.

22. Karvonen MJ. The effects of training on heart rate: A longitudinal study. Ann Med Exp Biol Fenn. 1957;35:307-15.

23. Ferris LT, Williams JS, Shen CL. The effect of acute exercise on serum brain-derived neurotrophic factor levels and cognitive function. Med 
Sci Sports Exerc. 2007;39(4):728-34.

24. Van Beekvelt M, Borghuis M, Van Engelen B, Wevers R, Colier W. Adipose tissue thickness affects in vivo quantitative near-IR spectroscopy in human skeletal muscle. Clin Sci. 2001;101(1):21-8.

25. Boushel R, Langberg H, Olesen J, Gonzales-Alonzo J, Bülow J, et al. Monitoring tissue oxygen availability with near infrared spectroscopy (NIRS) in health and disease. Scand J Med Sci Sports. 2001;11(4):21322.

26. Subudhi AW, Olin JT, Dimmen AC, Polaner DM, Kayser B, et al. Does cerebral oxygen delivery limit incremental exercise performance? J Appl Physiol. 2011;111(6):1727-34.

27. Ando S, Kokubu M, Yamada Y, Kimura M. Does cerebral oxygenation affect cognitive function during exercise? Eur J Appl Physiol. 2011; 111(9):1973-82.

28. Zauner A, Doppenberg E, Woodward J, Allen C, Jebraili S, et al. Multiparametric continuous monitoring of brain metabolism and substrate delivery in neurosurgical patients. Neurol Res. 1997;19(3):26573.

29. Secher NH, Seifert T, Van Lieshout JJ. Cerebral blood flow and metabolism during exercise: implications for fatigue. J Appl Physiol. 2008; 104(1):306-14.

30. Stroop JR. Studies of interference in serial verbal reactions. J Exp Psychol. 1935;18(6):643.

31. Kamijo K, Hayashi Y, Sakai T, Yahiro T, Tanaka K, et al. Acute effects of aerobic exercise on cognitive function in older adults. J Gerontol: Series B. 2009;64(3):356-63.

32. Cho SY, Kim JK, Roh HT. The Effect of Acute Aerobic Exercise Intensity on Human Brain Function Index and Cognition. Journal of Sport and Leisure Studies. 2013;52(2):727-36

33. Lee HH, Yoon JH, Jeong IG, Kim SH, Kim BK, et al. Effects of exercise intensity on hippocampal cell proliferation and BDNF expression in intracerebroventricular streptozotocin induced-memory impairment in rats. Exerc Sci. 2009;18(4):475-88.

34. Eo SJ, Leem YH, Kim DM. The Exercise-induced BDNF and synaptic proteins via PI3K/AKT on Hippocampal CA1 in aged mice. Exerc Sci. 2012;21(1):131-40

35. Kim YI, Cho SY. The Effects of 12 Weeks Cranial Electrotherapy Stimulation and Regular Aerobic Exercise on Blood Cortisol, Beta-endorphin, BDNF and Profile of Mood States (POMS) in Post-menopausal Middle-aged Women: Pilot Study. Exerc Sci. 2015;24(2):187-93. 36. Ding Q, Vaynman S, Akhavan M, Ying Z, Gomez-Pinilla F. Insulinlike growth factor I interfaces with brain-derived neurotrophic factormediated synaptic plasticity to modulate aspects of exercise-induced cognitive function. Neurosci. 2006;140(3):823-33.

37. Stefanini MO, Wu FT, Mac Gabhann F, Popel AS. A compartment model of VEGF distribution in blood, healthy and diseased tissues. BMC Syst Biol. 2008;2(1):77.

38. Meeusen R, Watson P, Hasegawa H, Roelands B, Piacentini MF. Central fatigue. Sports Med. 2006;36(10):881-909.

39. Brisswalter J, Collardeau M, René A. Effects of acute physical exercise characteristics on cognitive performance. Sports Med. 2002;32(9):55566.

40. Williams TB, Corbett J, McMorris T, Young JS, Dicks M, et al. Cognitive performance is associated with cerebral oxygenation and peripheral oxygen saturation, but not plasma catecholamines, during graded normobaric hypoxia. Exp Physiol. 2019;104(9):1384-97. 